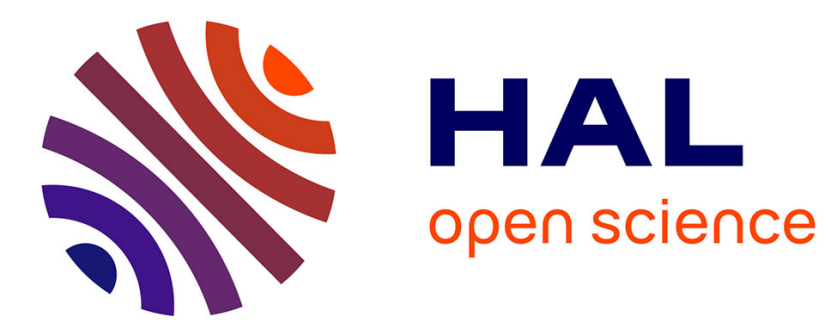

\title{
Landownership is an unexplored determinant of forest understory plant composition in Northern France
}

\author{
L. Bergès, C. Avon, K. Verheyen, J.L. Dupouey
}

\section{To cite this version:}

L. Bergès, C. Avon, K. Verheyen, J.L. Dupouey. Landownership is an unexplored determinant of forest understory plant composition in Northern France. Forest Ecology and Management, 2013, 306, p. 281 - p. 291. 10.1016/j.foreco.2013.06.064 . hal-00865850

\section{HAL Id: hal-00865850 \\ https://hal.science/hal-00865850}

Submitted on 25 Sep 2013

HAL is a multi-disciplinary open access archive for the deposit and dissemination of scientific research documents, whether they are published or not. The documents may come from teaching and research institutions in France or abroad, or from public or private research centers.
L'archive ouverte pluridisciplinaire HAL, est destinée au dépôt et à la diffusion de documents scientifiques de niveau recherche, publiés ou non, émanant des établissements d'enseignement et de recherche français ou étrangers, des laboratoires publics ou privés. 
Author-produced version of the article published in Forest Ecology and Management, 2013, Vol 306, 281-291

Regular paper

\section{Landownership is an unexplored determinant of forest understory plant composition in Northern France}

Laurent Bergès, Irstea, UR EMAX, CS 40061, 13182 Aix-en-Provence Cedex 5, France, laurent.berges@irstea.fr

Catherine Avon, Irstea, UR EMAX, CS 40061, 13182 Aix-en-Provence Cedex 5, France, catherine.avon@irstea.fr

Kris Verheyen, Ghent University, Laboratory of Forestry, Geraardsbergsesteenweg 267, 9090 Melle-Gontrode, Belgium, kris.verheyen@ugent.be

Jean-Luc Dupouey, INRA-Nancy University, Forest Ecology and Ecophysiology Unit, 54280 Champenoux, France, dupouey@nancy.inra.fr

Corresponding author: Laurent Bergès, Irstea, UR EMAX, CS 40061, 13182 Aix-en-Provence

Cedex 5, France, laurent.berges@irstea.fr, phone number: +33442669906 


\begin{abstract}
Few studies have investigated the influence of landownership on biodiversity. Therefore we analysed how the presence of forest understory plant species varied according to landownership in a broad geographical context and assessed which plant traits discriminated between species associated with state, other public or private forests. We also quantified the degree to which differences in soil type, forest management and landscape structure among ownership categories could explain the differences in species composition. Landownership, climate, soil, forest stand and landscape variables were collected on 38,751 plots located in temperate forests (5.1 Mha) in northern half of France using the French National Forest Inventory and GIS analyses. First, logistic regressions were used to determine species response to landownership after controlling for month of the plant survey and spatial autocorrelation. Relationships between plant traits and species association with landownership were then tested. Second, climate, soil, forest stand and landscape differences among ownerships were investigated. Third, species and trait responses to landownership were re-examined after controlling for month of the plant survey, spatial autocorrelation and climate, soil, forest stand and landscape variations.

Of the 276 species, 69 were associated with state forests, 38 with other public forests and 85 with private forests. Species associated with state and other public forests were more often urbanophobic, ancient-forest species, barochores and myrmecochores whereas private forest species were more often nutrient-, light-demanding, urbanophilic and endozoochorous species. Differences among landownerships were detected for all the soil, climate, forest management and landscape variables investigated. However, the ownership effect remained or became significant for 131 plants after controlling for environmental variability.

Landownership is not simply an administrative classification of land without ecological signification but was evidenced as a driver shaping understory plant community composition and plant traits in Northern France. These differences were partly explained by soil, management, edge and patch size effects, but land use history may help to explain the residual landownership effect. Our results have major implications on biodiversity monitoring and large-scaled conservation strategies. There is a need for deeper investigation into the impacts of land policy on biodiversity.
\end{abstract}

\title{
KEYWORDS
}

Landscape patterns, edge effect, past land use, plant traits, urbanity, dispersal mode. 
Author-produced version of the article published in Forest Ecology and Management, 2013, Vol 306, 281-291 Original publication available at http://www.sciencedirect.com

doi : 10.1016/j.foreco.2013.06.064

\section{INTRODUCTION}

Land-use change and ecosystem exploitation are considered the primary drivers of biodiversity loss (Foley et al., 2005). Reports suggest an influence of forest landownership on forest management practices, landscape heterogeneity and land-use change over time (Crow et al., 1999; Stanfield et al., 2002; Wimberly and Ohmann, 2004; Ohmann et al., 2007; Ko and He, 2011). However, few studies have considered the extent to which type of landownership is associated with differences in biodiversity (Lovett-Doust and Kuntz, 2001; Lovett-Doust et al., 2003; Ohmann et al., 2007). Two studies in Ontario reported differences among private, public and mixed-ownership sites in the number of vegetation community types, rare vascular plants, butterflies, mammals, and regionally- and locally-rare breeding birds, with higher numbers at public and mixed-ownership sites compared to privately-owned sites (Lovett-Doust and Kuntz, 2001; Lovett-Doust et al., 2003).

However, many environmental and disturbance factors such as soil, climate, land use history, present and past management practices and landscape characteristics can also vary strongly among landownerships and could thus explain the differences in biodiversity at first sight attributed to landownership (Maltamo et al., 1997; Lovett-Doust et al., 2003; Zmihorski et al., 2010; Riitters et al., 2012).

Publicly-owned land has been found to occur more often at higher elevation and on soils less suitable for agricultural production, having been spurned by private ownership due to its lower value for agriculture and forestry and difficulties with access (Wright et al., 2001). The same trend may have occurred in France, but the one study to address the issue only compared the distribution of soil types and soil chemical properties between forest and agricultural land; the authors found that cambisols, stagnic, gleyic luvisols, gleysols and podzols were more frequent in forested areas (Badeau et al., 1999). Focusing on forest management and disturbance regime, it has been established that forest ownership is a relevant factor for variations in forest vegetation (Ohmann et al., 2007) and forest structure (Maltamo et al., 1997; Wimberly and Ohmann, 2004). A recent study in central Poland (Zmihorski et al., 2010) showed that (i) private forests showed lower DBH and basal area than state forests, but (ii) state forests displayed higher proportions of non-native tree species (Robinia pseudoaccacia, Acer negundo, Prunus serotina and Platanus sp.). The differences in DBH and basal area could be partly explained by origin and age differences between state and private forests. First, a substantial proportion of the private forests could have originated from secondary succession and second, large connected patches were more often state-owned whereas small isolated patches were more often private (Zmihorski et al., 2010). This suggests that past land use and landscape fragmentation could also be involved in the observed differences between public and private lands. However, the higher proportion of non-native tree species would tend to suggest different and maybe more intense management practices and timber harvesting in state-owned forests.

Lovett-Doust \& Kuntz (2001) demonstrated that differences in biodiversity remained significant even after controlling for differences in landscape-level factors, which indicates a residual effect of landownership. This issue has yet to be explored in other geographical contexts and by controlling for a wider panel of environmental parameters (soil, climate and forest management). In this study, we focused on understory plants and basically assumed that plant species composition varied according to forest ownership (Fig. 1). However, we also hypothesised that the effect of forest ownership was actually attributable to a combination of environmental factors that differed among forest ownerships, i.e. abiotic conditions, forest management disturbances, landscape patterns and land-use history. Moreover, as species traits vary according to soil, climate, disturbance and landscape patterns, we assumed that plant traits also varied with forest ownership. We hypothesised that state forests were generally on less favourable site conditions than private lands, and thus would host species with lower nutrient 
requirements and indicator of wetter conditions. We also expected that private forest stands would be more intensively managed than public forests, and thus would be younger and have a lower stand basal area and volume and would host more disturbance-tolerant species, whereas public forests would host more disturbance-sensitive species. Finally, we expected a higher proportion of private forests to be recently afforested, smaller (Zmihorski et al., 2010) and often disconnected from ancient forests or preferentially located at their periphery (Bossuyt et al., 1999): thus, we hypothesised that fast-colonizing species would be more frequent in private forests while species with lower dispersal ability would be more frequent in state forests. In addition to these assumptions, we assumed that environmental conditions and plant trait responses in "other public" forests (run by local public, departmental or regional authorities or by public institutions) would be intermediate between state and private forests.

The three research questions addressed in this study were:

(1) to analyse plant species responses to forest ownership on a broad geographical scale and determine what plant traits discriminated preference for forest ownership among habitat requirements, dispersal mode and life form;

(2) to analyse landownership differences in climate, soil, forest management and landscape patterns;

(3) to re-examine both individual species and plant trait responses to forest ownership after controlling for climate, soil, forest management and landscape variations in order to test whether a residual landownership effect remains and, if so, to propose an ecological interpretation.

The use of the French National Forest Inventory dataset enabled us to explore very large gradients of environmental conditions and to properly disentangle the complex relationships among these factors.

\section{METHODS}

\subsection{Materials}

\subsubsection{Study area and French National Forest Inventory data}

In France, the total forest surface area (11.5 Mha) is 75\% privately-owned, 10\% (1.4 Mha) state-owned and 15\% (2.4 Mha) "other public" (Anonymous, 2010). Moreover, private forest units are highly parcelled out (a forest unit is the forest land that belongs legally to a single landowner entity): average unit size is just $2.9 \mathrm{ha}$ in private forest compared to $189 \mathrm{ha}$ in other public forest and a massive $1282 \mathrm{ha}$ in state forest (Anonymous, 2010).

The study area for this research covered the northern half of France with a surface area of $270,962 \mathrm{~km}^{2}$ and a forest cover of $20.4 \%$. Data came from the French National Forest Inventory (FNFI, http://inventaire-forestier.ign.fr/spip/) totalling 38751 plots distributed in 10131 forest patches (Fig. 2). Forest ownership (OWN) was composed of three classes: state forest (22\%), other public forest (mainly communal forests, $22 \%$ ) and private forest (56\%). Plots were located within one of the 133 FNFI-defined "ecoregions", i.e. the division of the country into homogeneous areas in terms of geomorphology, regional climate and forest management.

\subsubsection{Plant survey}

Plant species composition was surveyed inside $700 \mathrm{~m}^{2}$ circles at each plot throughout the year. Although the full study period was $1989-2009$, 97\% of the plots were sampled between 1990 and 2004. The data gathering process involved a total of 63 teams with a range of expertise in plant identification, which means random variation could be substantial due to observer effects, plant oversight and species misidentification (Archaux et al., 2006). However, we considered that the species distribution model was reliable because all the forest types were equally sampled and total sample size was huge. Plant phenology is also an important factor as it 
Author-produced version of the article published in Forest Ecology and Management, 2013, Vol 306, $281-291$ Original publication available at http://www.sciencedirect.com

doi : 10.1016/j.foreco.2013.06.064

affects the observed plant species composition, and so month of the plant survey was always included in our models as a covariate (MONTH). We did not control for year of survey. Nomenclature followed the French BDNFF flora nomenclature for vascular plants and the European BDNBE nomenclature for bryophytes (Tela-Botanica, 2011).

\subsubsection{Climate, topography and soil data}

These variables were recorded on-plot during field sampling or obtained from existing databases (Appendix A). Climate variables [mean annual precipitation (RAIN) and annual mean of monthly maximum temperatures (TMAX) from 1961 to 1990] were obtained using the AURELHY meteorological model built on a $1 \mathrm{~km}^{2}$ grid (Bénichou and Le Breton, 1987). We determined topography in the field using a topographical index measuring the difference between lateral water inflow and outflow of the plot (TOPO). The TOPO index increases as difference in flow increases. Soil characteristics were mainly based on soil type using a standardised soil classification (IUSS-Working-Group-WRB, 2006): the 41 initial classes were collapsed into 14 soil classes (SOIL) based on class frequency and similarities. Some plots were deleted due to the low frequency of soil classes and the impossibility of grouping into close categories. Other pedological variables were: humus type (HUMUS), depth of $\mathrm{HCl}$ effervescence in the fine soil fraction (DHCl), soil water capacity (SWC) and depth of temporary waterlogging (DTW).

\subsubsection{Forest stand variables}

Forest stand characteristics were collected in $1964 \mathrm{~m}^{2}$ circular plots and concerned total canopy cover (CCOV), stand age (AGE), stand basal area (BA), stand volume (VOL), dominant tree species of the overstory layer (TREE.SPECIES), forest stand structure (STRUC) and traces of felling or thinning (FELLING; Appendix A). The five most frequent tree species were: Quercus petraea (21\%), Q. robur (19\%), Fagus sylvatica (13\%), Pinus sylvestris (6\%) and Picea abies (5\%). Stand structure was composed of even-aged high forest (56\%), high forest with coppice (36\%), and coppice (8\%).

\subsubsection{Landscape variables}

Distance from the plot to the closest forest road (DIST.ROAD) was measured in the field using distance classes (Appendix A). Distance from the plot to the closest external edge of the forest patch (DIST.EDGE), size of the forest patch where the plot was located (FPS), forest surface area and number of forest patches within a 1000-m radius buffer around the plot (FA.1000 and NFP.1000) were calculated using GIS and FNFI forest maps (Appendix A).

\subsubsection{Plant traits}

Plant trait approach (Table 1) was mainly based on plant indicator values that have been extensively employed as indicators of abiotic conditions (Diekmann, 2003; Bergès et al., 2013). Ellenberg et al. (1992) and more recently Gégout et al. (2005) defined a set of indicator values for plants across central Europe and France, respectively. These values estimate the ecological optima of species along a series of environmental gradients.

To test the assumption that private forests were on richer soils and on less constraining conditions for waterlogging, we used $\mathrm{pH}$ for soil $\mathrm{pH}$ from EcoPlant database (Gégout et al., 2005), $\mathrm{N}$ for soil nitrogen and $\mathrm{F}$ for soil moisture from Ellenberg. We also used Ta for mean annual temperature from EcoPlant to detect large-scale vegetation variations among landownerships.

To test the assumption that private forests were more intensively managed and had lower basal area, we used L for light from Ellenberg and two indicator values of disturbance (hemeroby and urbanity) available in Bioflor database (Kühn et al., 2004). These authors assigned a hemeroby 
Author-produced version of the article published in Forest Ecology and Management, 2013, Vol 306, $281-291$ Original publication available at http://www.sciencedirect.com

doi : 10.1016/j.foreco.2013.06.064

level (degree of human impact) to most plants of the German flora. These levels were converted to a numerical index varying from 1 (ahemerobic or completely natural) to 7 (metahemerobic or completely artificial). Similarly, the urbanity index (i.e. tendency of the species to occur in urbanised areas) were rescaled in a 5-point scale ranging from 1 (urbanophobic) to 5

(urbanophilic).

To test the assumption that private forests were more recently afforested, of smaller size and often disconnected from ancient forests or preferentially located at their periphery, we used previous traits plus (i) preference for ancient forests (hereafter called ancient forest species: AFS) from a combination of the two lists provided by Hermy et al. (1999) for Europe and Dupouey et al. (2002) for France and (ii) eight dispersal modes from Julve (2011).

\subsection{Statistical analyses}

\subsubsection{Species response to landownership}

To avoid overparameterisation (Pellissier et al., 2013), species with fewer than 70 occurrences were excluded from the analysis. Thus 276 out of 645 species were retained for further analysis. Since our sampling area was very large, the statistical analysis should be adapted to the geographical distribution of the species within the study area to reduce uninformative absences. We therefore defined a sub-sample for each species by selecting all the plots of any ecoregion where the species occurred at least once. This approach created a spatial envelope for the species. The resulting species-specific sample size ranged from 1886 to 35520 plots while occurrences ranged from 70 to 19690.

A multiple logistic regression model was used to determine response of each species (i.e. probability of presence) to landownership (OWN) while controlling for the period of the relevé (MONTH) and spatial structure. Following Borcard et al. (1992), the spatial structure was modelled with the nine terms for a cubic trend surface analysis [centred geographical coordinates $(\mathrm{x}, \mathrm{y})$ of the grid squares, and the higher and cross-product terms $\left(\mathrm{x}^{2}, \mathrm{y}^{2}, \mathrm{x}^{3}, \mathrm{y}^{3}, \mathrm{xy}\right.$, $\mathrm{x}^{2} \mathrm{y}$ and $\left.\mathrm{xy}^{2}\right)$ ]. The best model $\mathrm{M}_{\text {SPATIAL }}$ was selected using a forward stepwise procedure based on the step function of the R stats package and considering MONTH with a quadratic term and cubic trend surface as predictors. Once $\mathrm{M}_{\text {SPATIAL }}$ was determined, landownership was added as a new predictor (MSPATIAL+OWN). This model was tested using AIC, and OWN was considered a significant predictor if the AIC difference between $\mathrm{M}_{\text {SPATIAL }}$ and $\mathrm{M}_{\text {SPATIAL+OWN }}$ was greater than 5 (which corresponds to $p<0.01$ ). Each species was assigned a response group for OWN according to the regression parameters associated to OWN effect: association with state forest, other public forest, private forest, or neutral response (non-significant).

\subsubsection{Variations in environmental factors among landownerships}

For nominal variables, we ran Chi-squared tests on the contingency tables crossing OWN with SOIL, HUMUS, DHCl, TOPO, DTW, TREE.SPECIES, STRUC, FELLING and DIST.ROAD. For continuous variables, we applied ANOVA to TMAX, RAIN, SWC, CCOV, AGE, BA, VOL, FPS, DIST.EDGE, FA.1000 and NFP.1000 using OWN as factor.

\subsubsection{Test of the species response to landownership after environmental correction} We tested whether the effect of landownership on species presence remained significant after controlling for climate, soil, forest management and landscape differences. The correlations among all predictors were first checked before analysis to avoid problems of multicollinearity. We removed HUMUS, DTW, DHCl, SWC, VOL, FPS and FA.1000 because they all displayed correlations above 0.54 . We kept PLUVIO and TMAX in the model despite correlations above 0.57 as it was too crude to model species ecological niche with only one climatic variable. We selected the best model MSPATIAL+ENVIR using a forward stepwise procedure as above considering $\mathrm{M}_{\text {SPATIAL }}$ as the lower model and the following list of additional predictors: TOPO, 
SOIL, TREE.SPECIES, STRUC, TMAX, RAIN, CCOV, AGE, DIST.EDGE and NFP.1000.

Continuous variables were always tested using a linear and a quadratic term, except for DIST.EDGE and NFP.1000 because we expected linear response to these landscape parameters. Once M MPATIAL+ENVIR was determined, landownership was added as a new predictor (MPATIAL+ENVIR+OWN) and tested using the same criterion as above. Each species was reassigned a response group for OWN effect according to the value of the re-adjusted parameter associated to OWN effect.

\subsubsection{Plant trait approach}

We ran Chi-squared tests on the contingency tables crossing each category of plant traits and species preference for landownership, before and after ENVIR correction.

All data calculations and statistical analyses were carried out using R software version 2.12.2 (R Foundation for Statistical Computing, Vienna, AT).

\section{RESULTS}

\subsection{Species and plant trait responses to landownership}

The model $\mathrm{M}_{\text {SPATIAL }}$ was always significant and included between 1 and 10 components with an average of 6.5. The most frequent components were MONTH, $\mathrm{x}, \mathrm{y}, \mathrm{x}^{3}$ and $\mathrm{x}^{2}$.

Of the 276 species analysed, 192 significantly responded to OWN, among which 69 were associated with state forests, 38 with other public forests and 85 with private forests. Twelve categories of plant traits (out of 18) showed significantly different proportions among the three types of landownership (Fig. 3). There were higher proportions of acidophiles $(\mathrm{pH}<4)$, urbanophobes (urbanity $\leq 1$ ) and barochores in the pool of state forest species. There were lower proportions of hygrophilous species $(F>6)$ and higher proportions of AFS and myrmecochores in the pool of other public forest species. There were higher proportions of basophiles $(\mathrm{pH}>7)$, nitrogen-demanding $(\mathrm{N}>6)$, light-demanding species ( $\mathrm{L} \geq 6)$, urbanophiles (urbanity $>3$ ), hemerobic species (hemeroby $>3$ ) and endozoochores in the pool of private forest species.

\subsection{Soil, climate, forest stand and landscape pattern variations among landowner types} All the ENVIR variables significantly varied among landowner types (Table 2). The following analysis only considers the variables for which the share of variance explained by ownership was above 1\%. For soil type (Fig. 4a), nutrient-poor soils and waterlogged soils were more frequent in state forests, whereas nutrient-rich soils were more frequent in private forests. For humus form, moder, dysmoder and mor were more frequent in state forests whereas eumull, carbonated mull and thick carbonated mull were more frequent in private forests. This trend was confirmed by the depth of a carbonated horizon, which was more often close to the soil surface in private forests and more often absent in state forests. TOPO and DTW showed weaker trends, but DTW displayed a higher share of superficially waterlogged soils in state forest compared to private forest. For climate, TMAX increased from other public to state then private forests, while RAIN followed the reverse gradient (Appendix B).

Stand characteristics also varied with landownership: AGE, VOL and FELLING all increased from private to other public then state forests, while DIST.ROAD was lowest in state forests (Fig. 4b, Appendix B). Concerning tree species composition, stands dominated by shadetolerant species ( $F$. sylvatica and Abies alba) were less frequent while those dominated by pioneer species (Alnus sp., Betula sp., Populus sp., Robinia pseudoacacia and Salix sp.) were more frequent in private forests (Fig. 4c). Stands dominated by $Q$. petraea were more frequent in state forests whereas those dominated by $Q$. robur were more frequent in private forests. The 
proportion of "even-aged high forest" was higher in state forests; the proportion of "high forest with coppice" was higher in other public forests and the proportion of "coppice" was much higher in private forests (Fig. 4d).

Concerning landscape patterns, DIST.EDGE, FPS and FA.1000 increased from private to other public forests then state forests, whereas NPF.1000 showed the opposite trend (Fig. 5). These trends were also clearly visible in Fig. 2.

\subsection{Species and plant trait responses to landownership after controlling for ENVIR}

All species responded to at least one ENVIR factor since the MSPATIAL+ENVIR model included between 2 and 10 environmental predictors (with an average of 7.1). SOIL and TREE.SPECIES were the most frequent predictors, showing that these two factors strongly determined the ecological niche of plant species in our study area.

Of the 276 species analysed, 126 significantly responded to OWN before and after ENVIR correction, while 66 responded to OWN before correction but not after. Five responded to OWN solely after ENVIR correction. Among the 131 species for which $\mathrm{M}_{\text {SPATIAL+ENVIR+OWN }}$ was the best model, 64 were associated with state forests, 26 with other public forests and 41 with private forests. The remaining 145 species showed a neutral response to landownership. Plants with indicator value for $\mathrm{pH}<4$ became non-significant after controlling for ENVIR variations (Appendix C). Conversely, two plant traits became significant after ENVIR correction: epizoochores (higher proportion in state forest species pool) and plants with indicator value for $\mathrm{Ta}>10^{\circ} \mathrm{C}$ (higher proportion in private forest species pool).

\section{DISCUSSION}

\subsection{Effect of landownership}

In total, $70 \%$ of the plants significantly responded to landownership while controlling for month of the plant survey and spatial structure, which confirmed our first assumption and underlined landownership as a driver of understory plant species distribution at a large geographical scale. Plant traits very often exhibited extreme proportions in state versus private forests, while other public forests presented intermediate values.

Thirty-four percent of the species that significantly responded to ownership became nonsignificant after controlling for soil, climate, forest management and landscape, which confirms our second assumption that many environmental factors related to landownership could partly explain plant response to landownership. Nevertheless, $66 \%$ of the species that significantly responded to ownership remained significant and most plant traits remained or became significant after environmental correction. Taken together, these results highlight that forest ownership had a residual effect on forest plant composition, in agreement with previous investigations (Lovett-Doust and Kuntz, 2001; Lovett-Doust et al., 2003). Our approach suggests that this residual effect of landownership should be related to other environmental factors not included in our models.

\subsection{Differences in abiotic conditions}

In accordance with our assumption, private forests were more often located on nutrient-rich soils than public forests (soil, humus form). Similarly, temporary waterlogging was observed at a lower depth in state forests, thus confirming wetter soil conditions in state forests. These soil differences corroborated that severe site conditions were less desirable for private ownership due to their lower suitability for agriculture (Wright et al., 2001). In addition, a substantial proportion of the private forested lands were likely to result from agricultural set-aside (Zmihorski et al., 2010). The European forest soil survey also revealed that forest soils in France were more acidic and superficially waterlogged than agricultural soils (Badeau et al., 
1999). However, after controlling for ENVIR variations, plant traits for $\mathrm{pH}$ and $\mathrm{N}$ still varied among landownerships (Appendix C), which means that ownership-related soil differences remained. Concerning climatic differences among ownerships (TMAX, RAIN), they mainly resulted from their spatial distribution within our study area: other public forests were more present in the eastern part of the study area, where climate is colder and wetter, while private forests were slightly more frequent in the south-centre part of the study area, where climate is warmer and drier. State forests were in average in an intermediate latitudinal position and more frequent at the north.

\subsection{Differences in forest management practises}

Forest management practises varied among ownership types: private forest stands were younger, had lower stand volume and were more often composed of pioneer tree species than state forests, whereas state and other public forests were more often composed of shade-tolerant species. Conversely, private forests displayed lower felling/thinning frequency and a larger distance to the closest forest road. As a result, it was difficult to conclude on the most intensively managed type of ownership: younger age and lower volume in private forests rather suggest shorter rotation length and thus more intensive silviculture, but this conclusion is contradicted by the lower felling/thinning frequency and longer distance to the closest road in private and other public forests. However, stand age and volume could be spurious indicators of management intensity, since they are also dependent on silvicultural treatment and tree species composition. A deeper investigation showed that silvicultural systems were not uniformly distributed among forest ownerships, as indicated by the higher proportion of even-aged high forest stands and the lower proportion of high forest with coppice in state forests. Either way, management practises are highly variable in privately-owned forests and vary according to forest unit size: large private forests (unit $>25 \mathrm{ha}$ ) representing about half of the private forest area tend to be more intensively managed since owners' main objective is timber production, whereas the other half of private forest area tends to be less intensively managed as the forest owners have multiple objectives such as firewood, recreation, hunting or heritage. Owners are not concerned in managing their small forests due to the high level of fragmentation observed of these privately-owned stands. In addition, economical studies indicates that in Western Europe, private owners are no more active farmers and are largely urbanised; thus they are not so interested in the economic value of their forests (Ziegenspeck et al., 2004). Conversely, state forest resources are likely to be more exploited as the market for biomass energy develops (Lattimore et al., 2009). Private forest owners in Western, Central and Eastern Europe are typically non-industrial private owners (Zmihorski et al., 2010). The context largely differs from Scandinavia or North America where the big private forest owners are industrial private owners (Maltamo et al., 1997; Ohmann et al., 2007).

Our results corroborate the hypothesis that private forests hosted more species associated to early-successional phases and disturbance-tolerant or disturbance-favoured species. Indeed, numbers of light- and nutrient-demanding species decrease with time since the last major disturbance, i.e. clearfelling, regeneration felling or plantation (Brunet et al., 1996; Zenner and Berger, 2008). Furthermore, other differences in silvicultural systems (Decocq et al., 2004; Gartner and Reif, 2005; Van Calster et al., 2007) and tree species composition (Augusto et al., 2003; Barbier et al., 2009 ;Wulf and Naaf, 2009) not related to forest succession could contribute to explain differences in plant composition and traits among ownerships.

\subsection{Differences in landscape patterns}

Landscape patterns displayed the highest correlations with landownership among the group of ENVIR factors (Table 2): private forests were closer to the external forest edge, in smaller forest patches and in more fragmented landscapes than public forests, consistently with our 
initial assumption (Zmihorski et al., 2010; Riitters et al., 2012). This suggests private forest is more prone to the influence of the surrounding matrix, in relation to processes occurring at the forest edge (Harper et al., 2005). Plant community composition generally indicated higher soil $\mathrm{pH}$, nitrogen availability and light availability at the forest edge than in the forest interior (Marchand and Houle, 2006; Vallet et al., 2010). Pioneer, ruderal, competitive, synanthropic and non-indigenous species were also more frequent at the forest edge (Honnay et al., 2002; Guirado et al., 2006), mainly due to the specific microclimatic conditions, higher agro-chemical inputs (Thimonier et al., 1992) and more frequent disturbances (Godefroid and Koedam, 2003a). Previous investigations on the same study area identified long depth-of-edge influence on understory plant species and traits (Pellissier et al., 2013): we crossed the two classifications [species association with OWN (3 classes) versus species preference according to distance-toedge (forest interior or forest edge)] and noted that $58 \%$ of forest-interior species preferred state forests while $66 \%$ of forest-edge species preferred private forests $\left(\mathrm{Chi}^{2}=52.3, d f=6\right.$, $p<0.0001)$.

Forest patch size reduction and isolation also impact forest plant communities. Patch isolation is reported to negatively affect AFS richness (Petit et al., 2004). Due to their closer proximity to potential sources (grasslands, arable fields or urban areas), plant communities in small forest patches are often characterized by more synanthropic and nutrient-demanding species but fewer AFS compared to communities in larger patches (Godefroid and Koedam, 2003b; Guirado et al., 2006).

The trait indicating human disturbance or naturalness (e.g. urbanity and hemeroby) very well discriminated plant response to ownership. Among the seven species qualified as "moderately urbanophilic" (urbanity =4) in Biolflor (Aesculus hippocastanum, Hyacinthoides non-scripta, Laburnum anagyroides, Pyrus communis, Ribes uva-crispa, Rubus ulmifolius and Sorbus domestica), all except $H$. non-scripta were significantly more frequent in private forests. This suggests that these two traits, which have developed for and tested in urban contexts (Hill et al., 2002), are equally reliable indicators of anthropogenic influence on a much broader environmental context. Including the quantity of urban, peri-urban and rural matrix in the surrounding landscape of the plots as additional landscape-level predictors of plant community composition would allow a deeper analysis of patterns of plant urbanity and hemeroby.

\subsection{Differences in past land use}

A significant share of variation in species distribution remained attached to landownership after correction for many environmental differences. We suspect that the residual effect of landownership could result from contrasted land use history between public and private lands (Zmihorski et al., 2010). The total forest surface area increased from 9.9 Mha to 15.6 Mha (+57\%) in France between 1908 and 2009, and this increase was divided into a small increase in state and other public forests and a huge increase in private forest ownership $(+0.2,+0.1$ and +5.4 Mha, respectively; Dupouey et al., unpublished). Moreover, preliminary results on a $7000 \mathrm{~km}^{2}$ region in the eastern part of our study area based on historical maps dating back to 1830 showed that the proportion of ancient forests was much higher in present-day state forests (90\%) and other public forests (88\%) than in private land (49\%), as also found in Eastern Europe (Zmihorski et al., 2010). Another argument that supports this historical interpretation is the legacy of past land use on forest soils and plant communities (e.g. Hermy and Verheyen, 2007; Plue et al., 2008).

Plant trait variations were largely consistent with the suspected remnant effect of former land use. The main evidence was the higher proportion of AFS in the public forest species pool (Fig. $3 \mathrm{~b}$ and Appendix C). Moreover, species associated with state forests were also more often barochores and myrmecochores, whereas species associated with private forests were more often endozoochores. These plant community differences in dispersal mode were previously 
observed between recent and ancient forests (Sciama et al., 2009). In addition, the private forest species pool showed higher indicator values for $\mathrm{pH}$ and $\mathrm{N}$, even after controlling for soil differences (Appendix C). This is probably because soils in recent forests generally have higher $\mathrm{pH}$, nutrient concentrations and nitrification rates than soils under ancient forests (Verheyen et al., 1999).

\section{CONCLUSIONS}

Landownership was evidenced as a driver shaping understory plant community composition and plant traits in Northern France. Thus, ownership is not an administrative classification of land without any ecological meaning. Forest land tenure results from a complex history where several drivers (soil, forest management, landscape and probably land use history differences) interact at large temporal and spatial scales. Our results have major implications on biodiversity monitoring and large-scaled conservation strategies, such as networks of protected areas. First, land ownership is easily available and synthesise several present and past disturbance factors that are more difficult to collect. Land ownership may thus be a useful indicator for forest biodiversity conservation policies. Second, governments in many regions concentrate conservation efforts on protected areas in public forests because this is more acceptable for the public. This strategy is actually rationale as the conservation value of public forests was higher due to their higher rate of ancient forest species and slow-colonising species, whereas private forests hosted more ruderal and synanthropic species. However, this strategy is incomplete because public forests only represent 25\% of the forested land in France. Moreover, important variations occur within private forests, concerning forest unit size, management intensity, forest fragmentation and land use history. All this means only a subset of environmental conditions and biodiversity is protected and particular attention might also be paid to privately-owned ancient forests. Moreover, major land use and ownership changes have occurred in Western Europe during the last two centuries (Eriksson et al., 2010). More recently, the growing challenge on forest bioenergy (including fuelwood) might further intensify forest management in public forests and large privately-owned forest units (shortening of forestry cycle duration, conversion of forests into short-rotation coppices, development of forest roads and access routes, increase in old tree harvesting) and thus might negatively impact biodiversity and ecosystem functioning (Lattimore et al., 2009 ; Bouget et al., 2012). Our findings underline that landownership policies can have major biodiversity impacts that we can no longer ignore.

\section{ACKNOWLEDGMENTS}

The authors thank T. Nedeltcheva, M. Duprez and C. Cluzeau from the French National Forest Inventory for providing the ecological databases and for their help during landscape parameter calculations and forest map database management. The authors thank two anonymous reviewers for their valuable comments on the manuscript. This study was partly funded by the Research Program "Biodiversité et Gestion Forestière" (BGF) of the French Ministry of Environment through the GIP Ecofor.

\section{REFERENCES}

Anonymous, 2010. Indicators for the Sustainable Management of French Forests. In. French Ministry of Agriculture, IFN, p. 202. Available at: http://inventaireforestier.ign.fr/spip/spip.php?article752.

Archaux, F., Gosselin, F., Bergès, L., Chevalier, R., 2006. Effects of sampling time, species richness and observer on the exhaustiveness of plant censuses. J Veg Sci 17, 299-306. 
Augusto, L., Dupouey, J.L., Ranger, J., 2003. Effects of tree species on understory vegetation and environmental conditions in temperate forests. Ann Forest Sci 60, 823-831.

Badeau, V., Dambrine, E., Walter, C., 1999. French forest soil properties: results of the first systematic survey. Etude et Gestion des Sols 6, 165-180.

Barbier, S., Chevalier, R., Loussot, P., Bergès, L., Gosselin, F., 2009. Improving biodiversity indicators of sustainable forest management: Tree genus abundance rather than tree genus richness and dominance for understory vegetation in French lowland oak hornbeam forests. Forest Ecol Manage 258, S176-S186.

Bénichou, P., Le Breton, O., 1987. Prise en compte de la topographie pour la cartographie des champs pluviométriques statistiques. La Météorologie 7, 23-34.

Bergès, L., Pellissier, V., Avon, C., Verheyen, K., Dupouey, J.L., 2013. Unexpected long-range edge-to-forest interior environmental gradients. Landscape Ecol 28, 439-453.

Borcard, D., Legendre, P., Drapeau, P., 1992. Partialling out the spatial component of ecological variation. Ecology 73, 1045-1055.

Bossuyt, B., Hermy, M., Deckers, J., 1999. Migration of herbaceous plant species across ancient-recent forest ecotones in central Belgium. J Ecol 87, 628-638.

Bouget, C., Lassauce, A., Jonsell, M., 2012. Effects of fuelwood harvesting on biodiversity - a review focused on the situation in Europe. Can J Forest Res 42, 1421-1432.

Brunet, J., FalkengrenGrerup, U., Tyler, G., 1996. Herb layer vegetation of south Swedish beech and oak forests - Effects of management and soil acidity during one decade. Forest Ecol Manage 88, 259-272.

Crow, T.R., Host, G.E., Mladenoff, D.J., 1999. Ownership and ecosystem as sources of spatial heterogeneity in a forested landscape, Wisconsin, USA. Landscape Ecol 14, 449-463.

Decocq, G., Aubert, M., Dupont, F., Alard, D., Saguez, R., Wattez-Franger, A., De Foucault, B., Delelis-Dusollier, A., Bardat, J., 2004. Plant diversity in a managed temperate deciduous forest: understorey response to two silvicultural systems. J Appl Ecol 41, 1065-1079.

Diekmann, M., 2003. Species indicator values as an important tool in applied plant ecology - a review. Basic Appl Ecol 4, 493-506.

Dupouey, J.L., Sciama, D., Dambrine, E., Rameau, J.C., 2002. La végétation des forêts anciennes. Revue Forestière Française 54, 521-532.

Ellenberg, H., Weber, H.E., Düll, R., Wirth, V., Werner, W., Pauliffen, D., 1992. Zeigerwerte von Pflanzen in Mitteleuropa. Scripta Geobotanica 18, 1-258.

Eriksson, S., Skanes, H., Hammer, M., Lonn, M., 2010. Current distribution of older and deciduous forests as legacies from historical use patterns in a Swedish boreal landscape (1725-2007). Forest Ecol Manage 260, 1095-1103.

Foley, J.A., DeFries, R., Asner, G.P., Barford, C., Bonan, G., Carpenter, S.R., Chapin, F.S., Coe, M.T., Daily, G.C., Gibbs, H.K., Helkowski, J.H., Holloway, T., Howard, E.A., Kucharik, C.J., Monfreda, C., Patz, J.A., Prentice, I.C., Ramankutty, N., Snyder, P.K., 2005. Global consequences of land use. Science 309, 570-574.

Gartner, S., Reif, A., 2005. The response of ground vegetation to structural change during forest conversion in the southern Black Forest. Eur J Forest Res 124, 221-231.

Gégout, J.C., Coudun, C., Bailly, G., Jabiol, B., 2005. EcoPlant: A forest site database linking floristic data with soil and climate variables. J Veg Sci 16, 257-260.

Godefroid, S., Koedam, N., 2003a. Distribution pattern of the flora in a peri-urban forest: an effect of the city-forest ecotone. Landscape Urban Plan 65, 169-185.

Godefroid, S., Koedam, N., 2003b. How important are large vs. small forest remnants for the conservation of the woodland flora in an urban context? Global Ecol Biogeogr 12, 287-298.

Guirado, M., Pino, J., Roda, F., 2006. Understorey plant species richness and composition in metropolitan forest archipelagos: effects of forest size, adjacent land use and distance to the edge. Global Ecol Biogeogr 15, 50-62. 
Harper, K.A., Macdonald, S.E., Burton, P.J., Chen, J.Q., Brosofske, K.D., Saunders, S.C., Euskirchen, E.S., Roberts, D., Jaiteh, M.S., Esseen, P.A., 2005. Edge influence on forest structure and composition in fragmented landscapes. Conserv Biol 19, 768-782.

Hermy, M., Honnay, O., Firbank, L., Grashof-Bokdam, C., Lawesson, J.E., 1999. An ecological comparison between ancient and other forest plant species of Europe, and the implications for forest conservation. Biol Conserv 91, 9-22.

Hermy, M., Verheyen, K., 2007. Legacies of the past in the present-day forest biodiversity: a review of past land-use effects on forest plant species composition and diversity. Ecol Res 22, 361-371.

Hill, M.O., Roy, D.B., Thompson, K., 2002. Hemeroby, urbanity and ruderality: bioindicators of disturbance and human impact. J Appl Ecol 39, 708-720.

Honnay, O., Verheyen, K., Hermy, M., 2002. Permeability of ancient forest edges for weedy plant species invasion. Forest Ecol Manage 161, 109-122.

IUSS-Working-Group-WRB, 2006. World reference base for soil resources.

Julve, P., 2011. Baseflor. < http://philippe.julve.pagesperso-orange.fr/catminat.htm> (accessed October 2011).

Ko, D.W., He, H.S., 2011. Characterizing the historical process of private forestland ownership parcelization and aggregation in the Missouri Ozarks, USA, from 1930 to 2000. Landscape Urban Plan 102, 262-270.

Kühn, I., Durka, W., Klotz, S., 2004. BiolFlor - a new plant-trait database as a tool for plant invasion ecology. Divers Distrib 10, 363-365.

Lattimore, B., Smith, C.T., Titus, B.D., Stupak, I., Egnell, G., 2009. Environmental factors in woodfuel production: Opportunities, risks, and criteria and indicators for sustainable practices. Biomass Bioenerg 33, 1321-1342.

Lovett-Doust, J., Biernacki, M., Page, R., Chan, M., Natgunarajah, R., Timis, G., 2003. Effects of land ownership and landscape-level factors on rare-species richness in natural areas of southern Ontario, Canada. Landscape Ecol 18, 621-633.

Lovett-Doust, J., Kuntz, K., 2001. Land ownership and other landscape-level effects on biodiversity in southern Ontario's Niagara Escarpment Biosphere Reserve, Canada. Landscape Ecol 16, 743-755.

Maltamo, M., Uuttera, J., Kuusela, K., 1997. Differences in forest stand structure between forest ownership groups in central Finland. J Environ Manage 51, 145-167.

Marchand, P., Houle, G., 2006. Spatial patterns of plant species richness along a forest edge: What are their determinants? Forest Ecol Manage 223, 113-124.

Ohmann, J.L., Gregory, M.J., Spies, T.A., 2007. Influence of environment, disturbance, and ownership on forest vegetation of Coastal Oregon. Ecol Appl 17, 18-33.

Pellissier, V., Bergès, L., Nedeltcheva, T., Schmitt, M.C., Avon, C., Cluzeau, C., Dupouey, J.L., 2013. Understory plant species show long-range spatial patterns in forest patches according to distance-to-edge. J Veg Sci 24, 9-24.

Petit, S., Griffiths, L., Smart, S.S., Smith, G.M., Stuart, R.C., Wright, S.M., 2004. Effects of area and isolation of woodland patches on herbaceous plant species richness across Great Britain. Landscape Ecol 19, 463-471.

Plue, J., Hermy, M., Verheyen, K., Thuillier, P., Saguez, R., Decocq, G., 2008. Persistent changes in forest vegetation and seed bank 1,600 years after human occupation. Landscape Ecol 23, 673-688.

Riitters, K.H., Coulston, J.W., Wickham, J.D., 2012. Fragmentation of forest communities in the eastern United States. Forest Ecol Manage 263, 85-93.

Sciama, D., Augusto, L., Dupouey, J.L., Gonzalez, M., Dominguez, C.M., 2009. Floristic and ecological differences between recent and ancient forests growing on non-acidic soils. Forest Ecol Manage 258, 600-608. 
Stanfield, B.J., Bliss, J.C., Spies, T.A., 2002. Land ownership and landscape structure: a spatial analysis of sixty-six Oregon (USA) Coast Range watersheds. Landscape Ecol 17, 685-697.

Thimonier, A., Dupouey, J.L., Timbal, J., 1992. Floristic changes in the herb-layer vegetation of a deciduous forest in the Lorraine Plain under the influence of atmospheric deposition. Forest Ecol Manage 55, 149-167.

Vallet, J., Beaujouan, V., Pithon, J., Roze, F., Daniel, H., 2010. The effects of urban or rural landscape context and distance from the edge on native woodland plant communities. Biodivers Conserv 19, 3375-3392.

Van Calster, H., Baeten, L., De Schrijver, A., De Keersmaeker, L., Rogister, J.E., Verheyen, K., Hermy, M., 2007. Management driven changes (1967-2005) in soil acidity and the understorey plant community following conversion of a coppice-with-standards forest. Forest Ecol Manage 241, 258-271.

Verheyen, K., Bossuyt, B., Hermy, M., Tack, G., 1999. The land use history (1278-1990) of a mixed hardwood forest in western Belgium and its relationship with chemical soil characteristics. J Biogeogr 26, 1115-1128.

Wimberly, M.C., Ohmann, J.L., 2004. A multi-scale assessment of human and environmental constraints on forest land cover change on the Oregon (USA) coast range. Landscape Ecol 19, 631-646.

Wright, R.G., Scott, J.M., Mann, S., Murray, M., 2001. Identifying unprotected and potentially at risk plant communities in the western USA. Biol Conserv 98, 97-106.

Wulf, M., Naaf, T., 2009. Herb layer response to broadleaf tree species with different leaf litter quality and canopy structure in temperate forests. J Veg Sci 20, 517-526.

Zenner, E.K., Berger, A.L., 2008. Influence of skidder traffic and canopy removal intensities on the ground flora in a clearcut-with-reserves northern hardwood stand in Minnesota, USA. Forest Ecol Manage 256, 1785-1794.

Ziegenspeck, S., Hardter, U., Schraml, U., 2004. Lifestyles of private forest owners as an indication of social change. Forest Policy Econ 6, 447-458.

Zmihorski, M., Chylarecki, P., Rejt, L., Mazgajski, T.D., 2010. The effects of forest patch size and ownership structure on tree stand characteristics in a highly deforested landscape of central Poland. Eur J Forest Res 129, 393-400. 
Table 1. Overview of the plant traits analysed.

\begin{tabular}{|c|c|c|c|c|}
\hline Traits & Description and range & Scale & $\begin{array}{l}\text { Number (and \%) } \\
\text { of species with } \\
\text { trait data } \\
\text { available }\end{array}$ & Main data source \\
\hline $\mathrm{pH}$ & soil pH [3- 8.5] & pH Unit & $256(93 \%)$ & Gégout et al. (2005) \\
\hline $\mathrm{N}$ & soil nitrogen: from 1 to 9 (nitrogen-demanding) & Ordinal & $205(74 \%)$ & Ellenberg et al. (1992) \\
\hline $\mathrm{F}$ & soil humidity: from 1 to 9 (moisture-demanding) & Ordinal & $224(81 \%)$ & Ellenberg et al. (1992) \\
\hline Ta & mean annual air temperature [3.8 - 15.7] & ${ }^{\circ} \mathrm{C}$ & $244(88 \%)$ & Gégout et al. (2005) \\
\hline $\mathrm{L}$ & light: from 1 to 9 (light-demanding) & Ordinal & $250(91 \%)$ & Ellenberg et al. (1992) \\
\hline Urbanity & 5 classes: from 1 , urbanophobic to 5 , urbanophilic & Ordinal & $236(86 \%)$ & Kühn et al. (2004) \\
\hline Hemeroby & $\begin{array}{l}7 \text { classes: } 1 \text {, ahemerobic; } 2 \text {, oligohemerobic; 3, mesohemerobic; } 4 \text {, } \\
\text { beta-euhemerobic; } 5 \text {, alpha-euhemerobic; } 6 \text {, polyhemerobic"; } 7 \text {, } \\
\text { metahemerobic }\end{array}$ & Ordinal & $237(86 \%)$ & Kühn et al. (2004) \\
\hline $\begin{array}{l}\text { Ancient } \\
\text { forest } \\
\text { species }\end{array}$ & 2 classes: species classified as AFS or not & Nominal & 276 (100\%) & $\begin{array}{l}\text { Hermy et al. (1999) } \\
\text { and Dupouey et al. } \\
(2002)\end{array}$ \\
\hline $\begin{array}{l}\text { Dispersal } \\
\text { mode }\end{array}$ & $\begin{array}{l}8 \text { classes: anemochory, autochory (bryophytes), barochory, } \\
\text { hydrochory, myrmecochory, epizoochory, endozoochory, } \\
\text { dyszoochory }\end{array}$ & Nominal & 256 (93\%) & Julve (2011) \\
\hline
\end{tabular}


Table 2. Results of Chi-square tests or ANOVA $\left(\mathrm{R}^{2}\right)$ on the relationship between i) soil, climate, forest stand, landscape patterns and ii) landownership. For continuous variables, the mean of the ownership class was ranked numerically in increasing order, based on multiple comparisons of means (lowercase letters indicate significant ownership differences). Even if significant, results were not detailed for $\mathrm{R}^{2}$ values below 0.01 . Significance is flagged as: $*=$ $p<0.05 ; * *=p<0.01 ; * * *=p<0.001$.

\begin{tabular}{|c|c|c|c|c|c|c|}
\hline $\begin{array}{l}\text { Nominal } \\
\text { variable }\end{array}$ & $\begin{array}{l}\text { Chi- } \\
\text { square }\end{array}$ & $\mathrm{df}$ & p-value & & & \\
\hline SOIL & 1958.6 & 26 & $* * *$ & & & \\
\hline HUMUS & 1589.2 & 24 & $* * *$ & & & \\
\hline $\mathrm{DHCl}$ & 570.1 & 10 & $* * *$ & & & \\
\hline TOPO & 113.3 & 6 & $* * *$ & & & \\
\hline DTW & 292.2 & 10 & $* * *$ & & & \\
\hline TREE.SPECIES & 4425.0 & 36 & $* * *$ & & & \\
\hline STRUC & 2820.7 & 4 & $* * *$ & & & \\
\hline FELLING & 856.8 & 2 & $* * *$ & & & \\
\hline DIST.ROAD & 316.1 & 6 & $* * *$ & & & \\
\hline \multirow{2}{*}{$\begin{array}{l}\text { Continuous } \\
\text { variable }\end{array}$} & \multirow[t]{2}{*}{$\mathrm{R}^{2}$} & & \multirow[t]{2}{*}{ p-value } & \multicolumn{3}{|c|}{ Ownership rank } \\
\hline & & & & State & $\begin{array}{l}\text { Other } \\
\text { public }\end{array}$ & Private \\
\hline TMAX & 0.075 & & $* * *$ & $2 b$ & $1 \mathrm{a}$ & 3c \\
\hline RAIN & 0.056 & & $* * *$ & $2 b$ & 3c & $1 \mathrm{a}$ \\
\hline SWC & $<0.01$ & & $*$ & - & - & - \\
\hline $\mathrm{CCOV}$ & $<0.01$ & & $* * *$ & - & - & - \\
\hline AGE & 0.019 & & $* * *$ & 3c & $2 b$ & $1 \mathrm{a}$ \\
\hline BA & $<0.01$ & & $* * *$ & - & - & - \\
\hline VOL & 0.013 & & $* * *$ & 3c & $2 b$ & $1 \mathrm{a}$ \\
\hline DIST.EDGE & 0.124 & & $* * *$ & 3c & $2 b$ & $1 \mathrm{a}$ \\
\hline FPS & 0.114 & & $* * *$ & 3c & $2 b$ & $1 \mathrm{a}$ \\
\hline FA.1000 & 0.176 & & $* * *$ & $3 c$ & $2 b$ & $1 \mathrm{a}$ \\
\hline NFP.1000 & 0.090 & & $* * *$ & $1 \mathrm{a}$ & $2 b$ & $3 c$ \\
\hline
\end{tabular}

\section{Figure Captions}

Fig. 1. Conceptual framework of the relationships among the environmental drivers and understory plant response.

Fig. 2. Location of the 38,751 plots studied in the northern half of France with a regional focus to illustrate the specific spatial pattern of landownership. 
Fig. 3. Percentage of species for each plant trait category according to species association with landownership: (a) indicator values (IV) for soil $\mathrm{pH}(\mathrm{pH})$, soil nitrogen availability ( $\mathrm{N})$, soil humidity (F), air temperature (Ta), light availability (L), urbanity and hemeroby; (b) preference for ancient forests (AFS) and dispersal mode. Percentages show the proportion of species having a given trait among the total number of species associated with state, other public, or private forests. The Chi-squared test indicates whether there is a significant difference in proportion among landownerships. Species with neutral response to landownership and species with missing values for plant traits were not included in the test. Number of missing values: pH: 6; N: 45; F: 39; Ta: 14; L: 15; urbanity: 23; hemeroby: 21; dispersal mode: 11.

Fig. 4. (a) Proportions of soil types according to landownership. Proportions are relative to the total number of plots in each type of landownership. Soil types are ranked in ascending order of soil $\mathrm{pH}$. (b) Proportion of plots with distance to the closest forest road $>500 \mathrm{~m}$ and proportion of plots with traces of felling/thinning according to landownership. (c) Proportions of dominant tree species according to landownership. Tree species are grouped according to their response profile. (d) Proportions of even-aged high forest, high forest with coppice, and coppice according to landownership.

Fig. 5. Boxplot of distance-to-edge (DIST.EDGE, $m$, log scale), forest patch size (FPS, ha, log scale), forest surface area and number of forest patches within a 1000- $m$ radius buffer around the plot (FA.1000, ha and NFP.1000) according to landownership. All the relationships were highly significant $(p<0.0001)$. The horizontal dotted lines correspond to grand mean values. "OTH.PUB.": other public forests. 
Author-produced version of the article published in Forest Ecology and Management, 2013, Vol 306, 281-291 Original publication available at http://www.sciencedirect.com

doi : 10.1016/j.foreco.2013.06.064

Fig. 1.

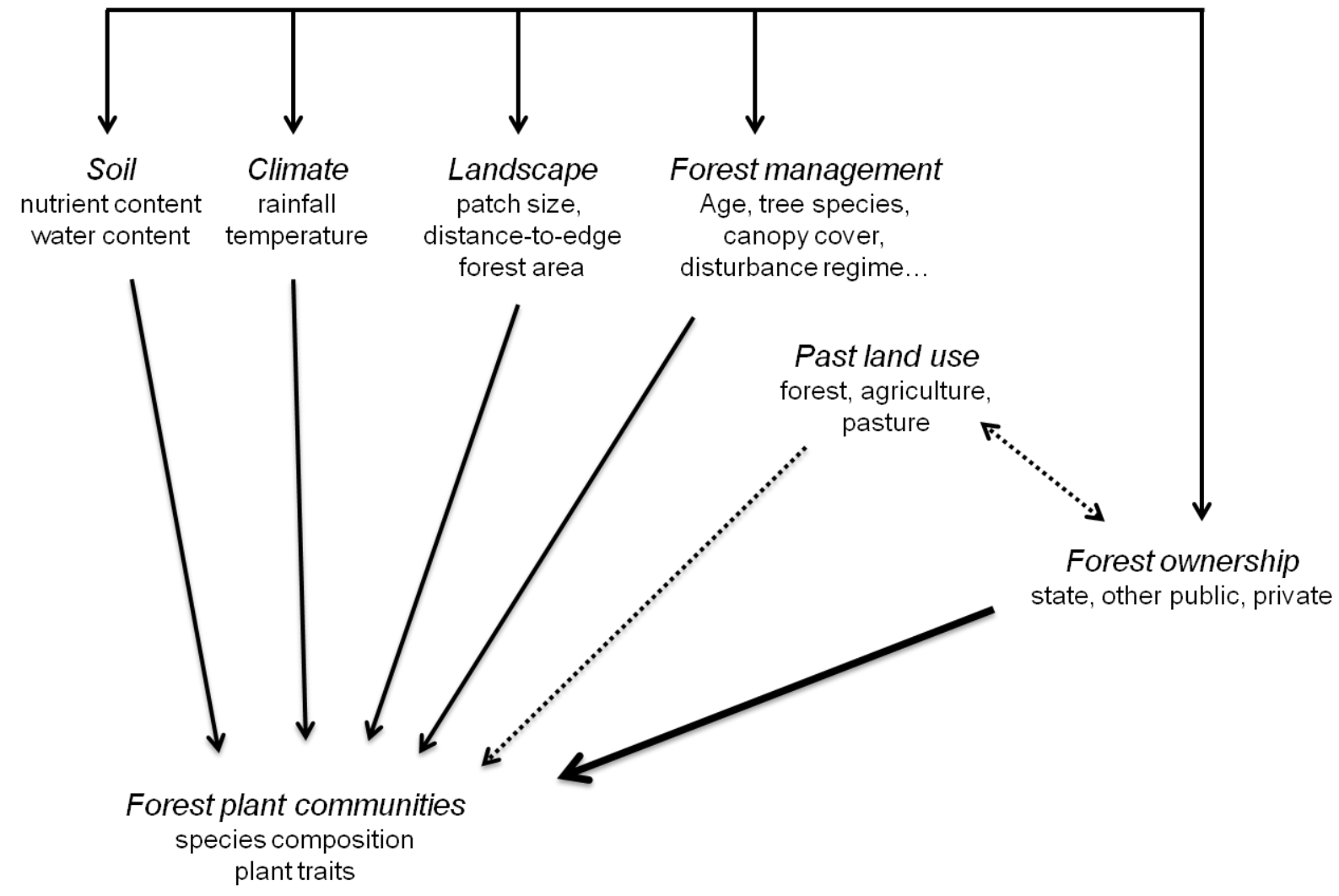


Author-produced version of the article published in Forest Ecology and Management, 2013, Vol 306, 281-291 Original publication available at http://www.sciencedirect.com

doi : 10.1016/j.foreco.2013.06.064

Fig. 2.

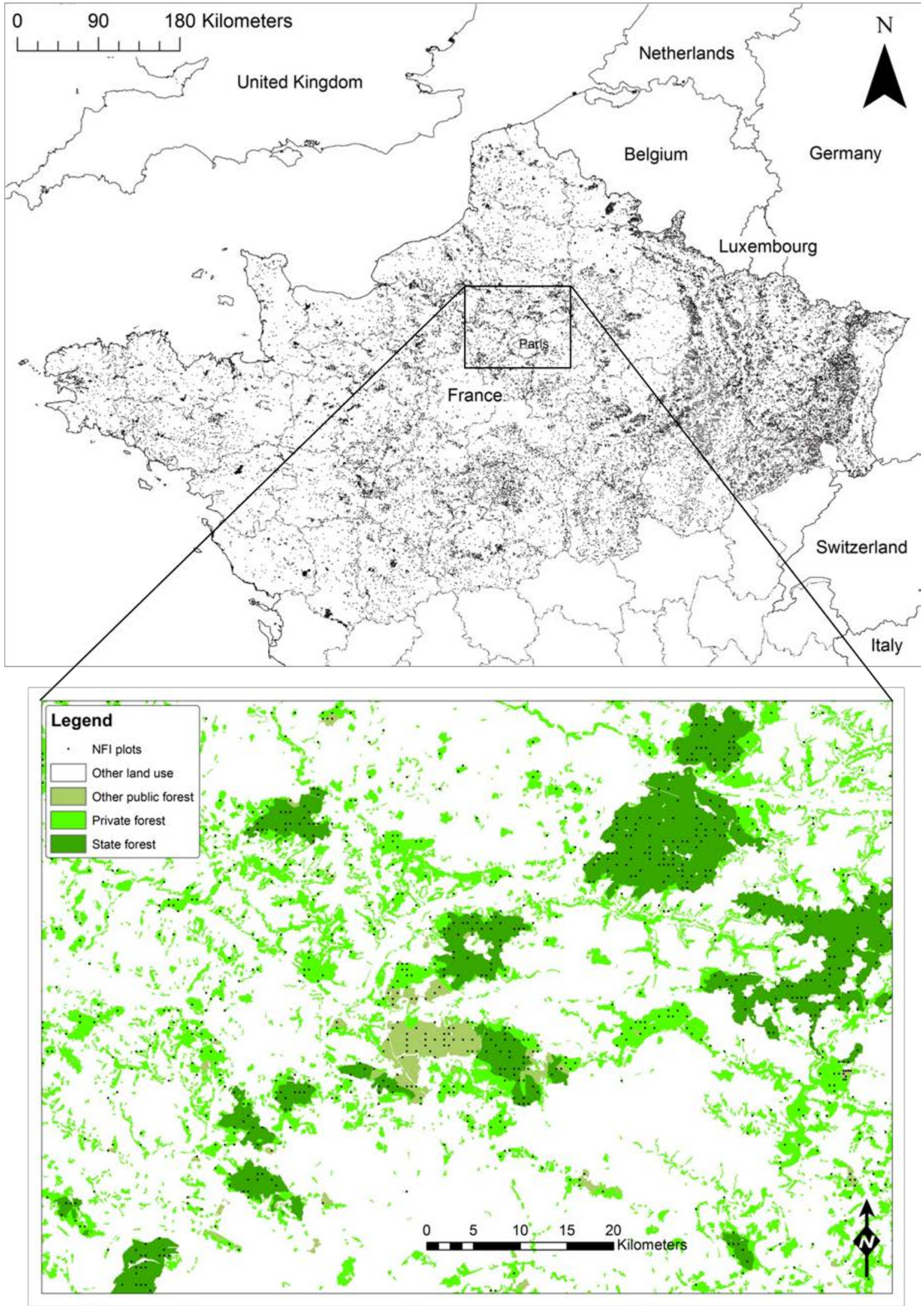


Author-produced version of the article published in Forest Ecology and Management, 2013, Vol 306, 281-291 Original publication available at http://www.sciencedirect.com

doi : 10.1016/j.foreco.2013.06.064

\section{Fig. 3.}

(a)

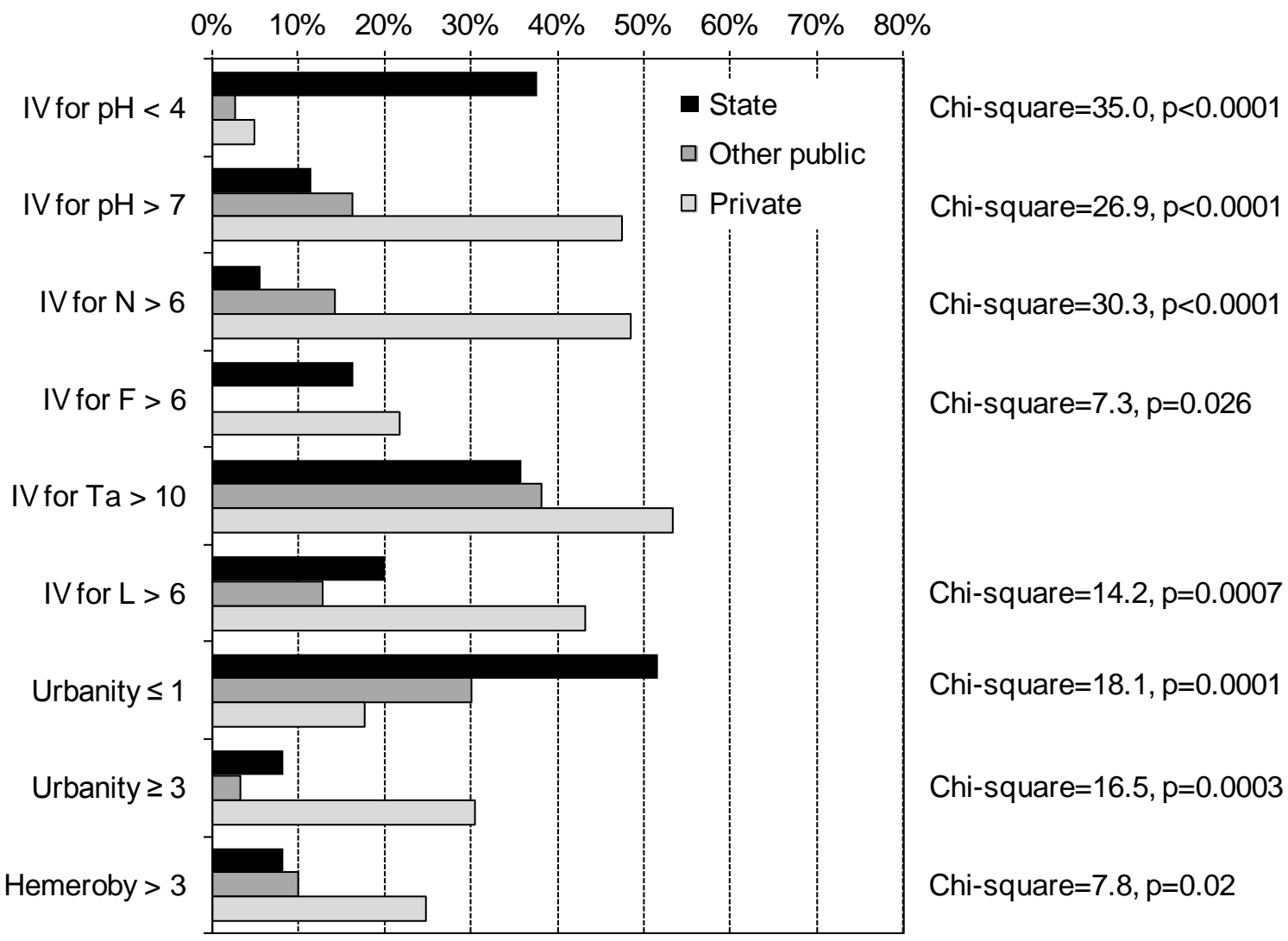

(b)

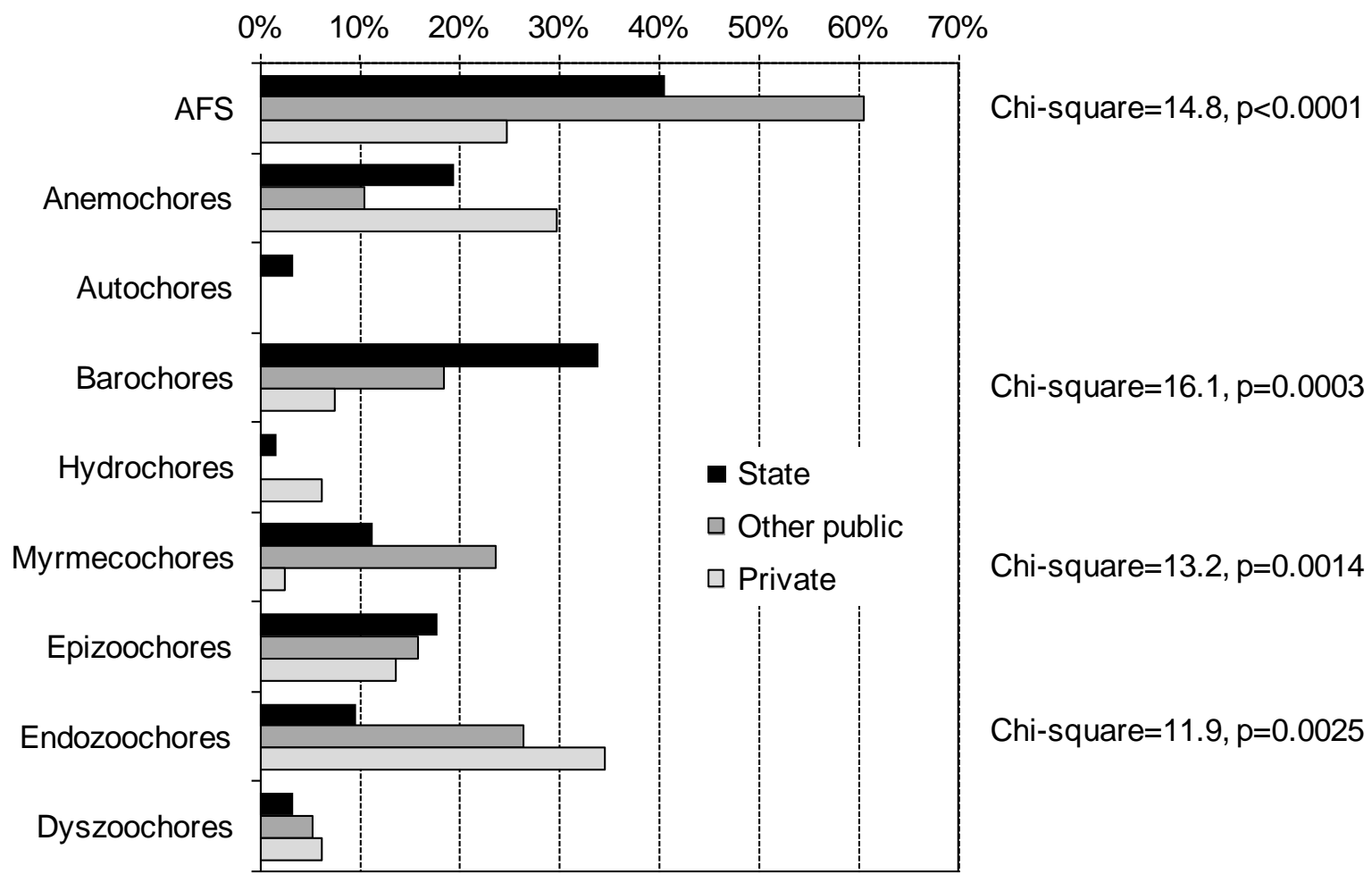


Author-produced version of the article published in Forest Ecology and Management, 2013, Vol 306, 281-291 Original publication available at http://www.sciencedirect.com doi : 10.1016/j.foreco.2013.06.064

Fig. 4.

(a)

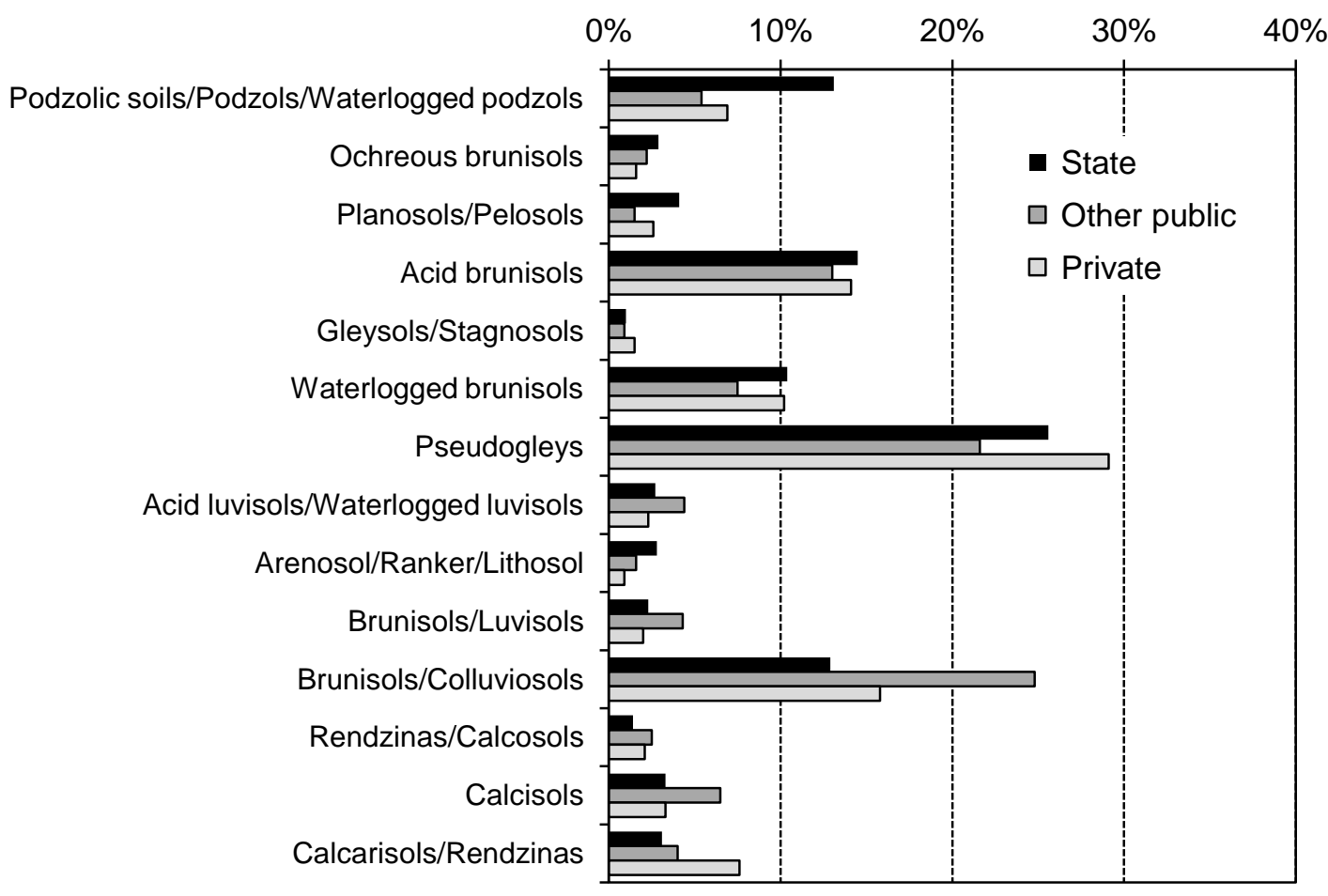

(b)

Distance to the closest forest road $>500 \mathrm{~m}$

Presence of felling/thinning

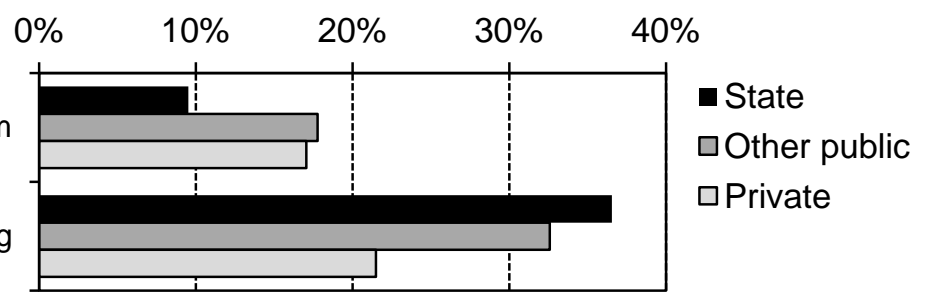


Author-produced version of the article published in Forest Ecology and Management, 2013, Vol 306, 281-291 Original publication available at http://www.sciencedirect.com doi : 10.1016/j.foreco.2013.06.064

Fig. 5.
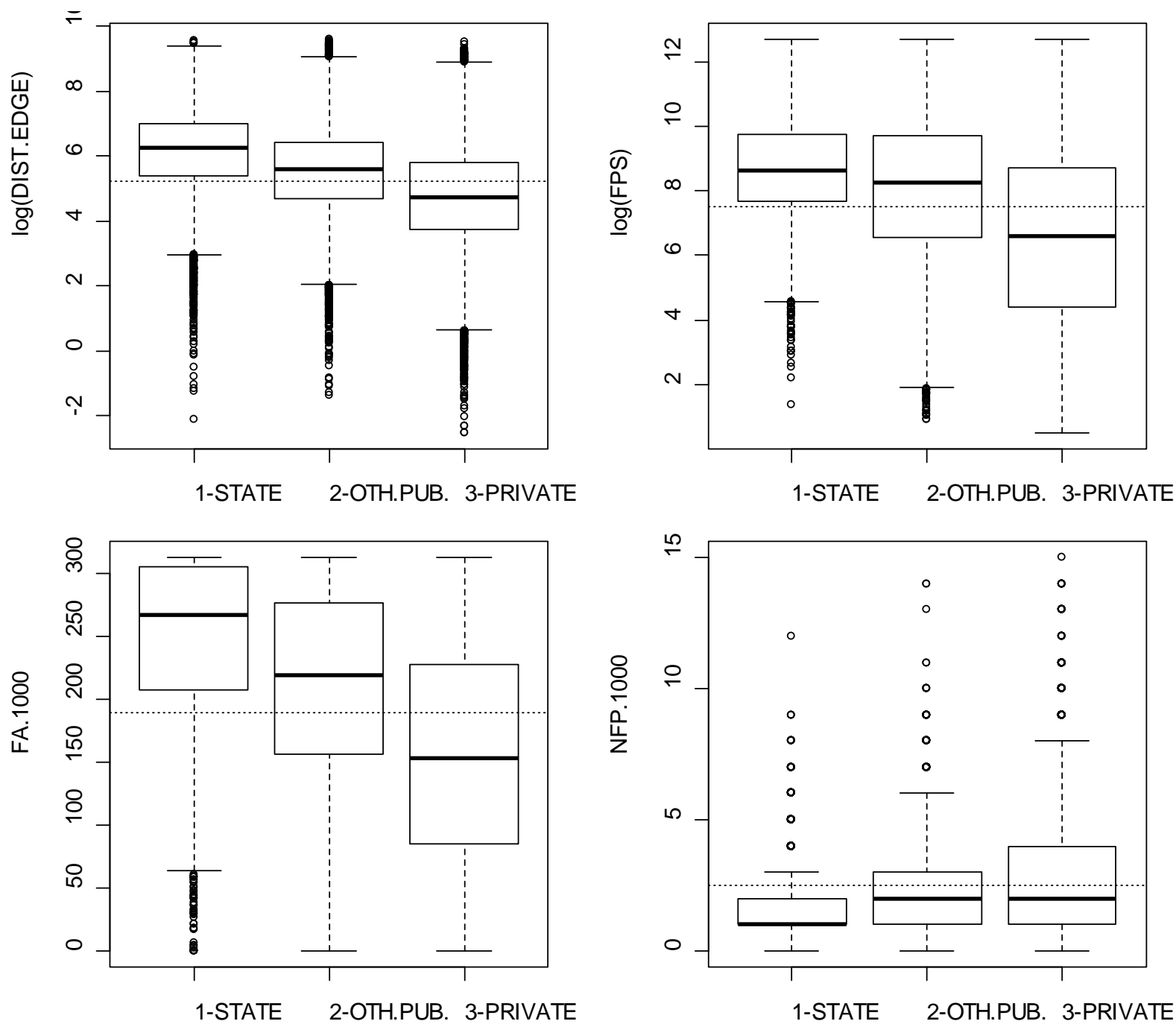